\title{
The Impact of Financial Inclusion on Economic Growth, Poverty, Income Inequality, and Financial Stability in Asia
}

\author{
Kusuma RATNAWATI ${ }^{1}$
}

Received: July 30, 2020 Revised: August 23, 2020 Accepted: September 03, 2020

\begin{abstract}
As an effort to achieve sustainable development and increase people's welfare, financial inclusion has become the policy agenda of many countries. Therefore, the effect of financial inclusion on economic growth, poverty, income inequality, and financial stability in several countries in Asia has become the goal and this is the subject of this study. Financial inclusion is measured by 3 dimensions, namely banking penetration, access to banking services, and use of banking services. Poverty ratio below the national poverty line and the Gini coefficient are used as indicators of poverty and income inequality. Financial stability is measured by Bank Z-Score and bank nonperforming loans. The results from the hypothesis test shows that all dimensions of financial stability simultaneously have significant influence on economic growth, poverty, income inequality, and financial stability. On the other hand, the partial impact of financial inclusion dimension on economic growth, poverty alleviation, income inequality, and financial stability in ten countries of Asia has not been optimal. The derived results of this study is required to be interpreted and considered by the Governments of each country in developing strategies for increasing financial inclusion, so that the policy to achieve sustainable development and enhancement of people's welfare can be achieved.
\end{abstract}

Keywords: Financial Inclusion, Economic Growth, Poverty, Income Inequality, Financial Stability

JEL Classification Code: O1, G2, I3

\section{Introduction}

Financial inclusion has become a topic in the global policy agenda since early 2000. Many countries use financial inclusion as an effort to achieve more equitable economic growth (Collard, 2010). The United Nation (UN) set financial inclusion as one of the main goals in the Millennium Development Goals (MDG) to achieve sustainable development and improve the world welfare that is based on human rights and equality to encourage social, economic, and environmental development.

According to Pearce (2011), the importance of financial inclusion is now widely recognized, even become a policy

${ }^{1}$ First Author and Corresponding Author. Department of Management, Faculty of Economics and Business, Universitas Brawijaya, Malang, Indonesia [Postal Address: Jl. Veteran, Ketawanggede, Kec. Lowokwaru, Kota Malang, Jawa Timur 65145, Indonesia] Email: kusuma@ub.ac.id

(c) Copyright: The Author(s)

This is an Open Access article distributed under the terms of the Creative Commons Attribution Non-Commercial License (https://creativecommons.org/licenses/by-nc/4.0/) which permits unrestricted non-commercial use, distribution, and reproduction in any medium, provided the original work is properly cited. priority in many countries. Financial inclusion plays an important role in building a strong foundation of a country's financial infrastructure, which in turn will facilitate its economic growth and development (Sharma, 2016). Policy makers in Asian countries have taken different steps to increase the access to financial service for those who are excluded from the financial sector. The government in Indonesia increases financial inclusion through the People's Business Loans (KUR), E-Money, and microfinance service improvements. Thailand has two specialized institutions to achieve increased financial inclusion, namely the Village Fund and Bank for Agriculture and Agricultural Cooperatives (BACC). India applies several programs such as Agent Banking, Mobile Banking, and unique innovation such as Biometrical Scanning System (Asian Development Bank, 2014).

Steps to increase the access to financial services for all societies in various Asian countries has resulted in rapid expansion of financial inclusion over the past decade. The World Bank reported a very rapid increase in financial inclusion in several Asian countries. The financial inclusion index increased significantly in almost all countries in Asia, 
such as in Malaysia which reached 80.7 in 2014, which is a increase of 14.5 percent from 2011; while in India and Indonesia it increased by 2 times in 2014 compared to 2011 (World Bank, 2015) (see Figure 1).

The main objective of financial inclusion programs carried out by countries in Asia is to encourage inclusive growth through reducing poverty, increasing development, income distribution, and financial system stability (Bank Indonesia, 2014). However, the rapid increase of financial inclusion in Asia in 2014 was not accompanied by an increase in economic growth; even some countries experienced an economic slowdown. The data of economic growth in Asia reported by the Asian Development Bank in Figure 1 shows the Gross Domestic Product (GDP) growth rate of several countries experienced a sharp decline in 2014.
In Figure 1, it can be seen that Thailand, Singapore, Indonesia, the Philippines, and several other countries experienced a decline in GDP growth rates as well as income inequality in 2014. Based on the data from the World Bank (2016) as presented in Figure 2(a), income inequality in the last few decades has increased in several Asian countries. This shows that the main objective of financial inclusion which theoretically can increase the economic growth and reduce income inequality is not in accordance with the phenomenon in Asia. On the other hand, poverty rates in several Asian countries have decreased significantly, as Figure 2(b) shows a drastic reduction in the ratio of poor population in Asia. Thus, the increase of financial inclusion in Asia in the last few decades is accompanied by a reduction in poverty levels, which is consistent with the aims of financial inclusion (see Figure 2).
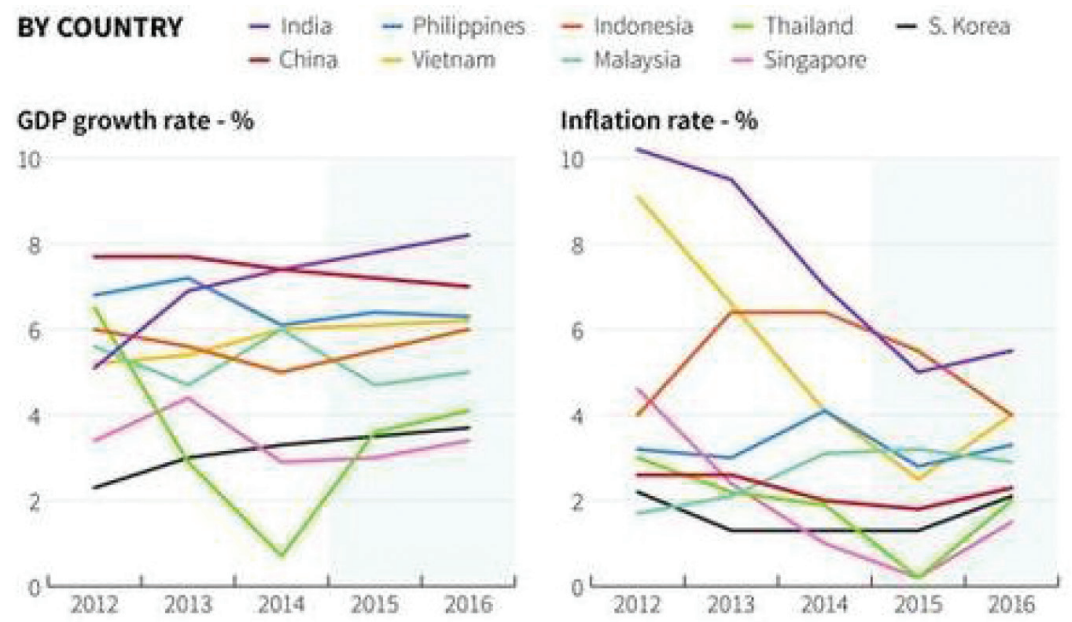

Figure 1: GDP Growth Rates in Several Countries in Asia Source: Asian Development Bank

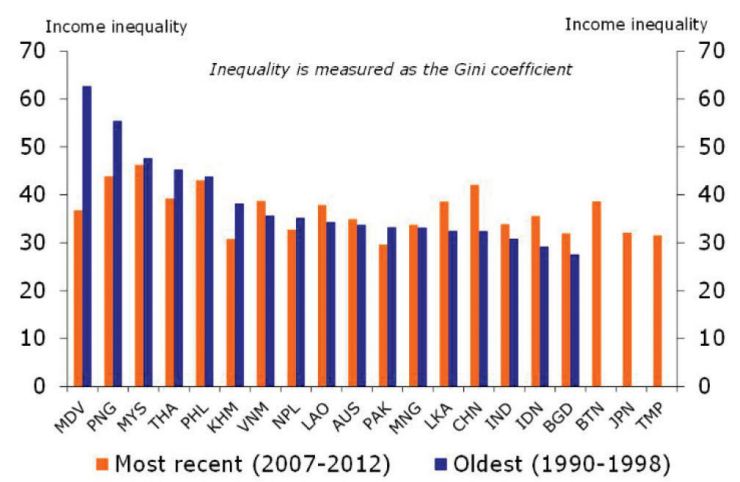

a. Income Inequality

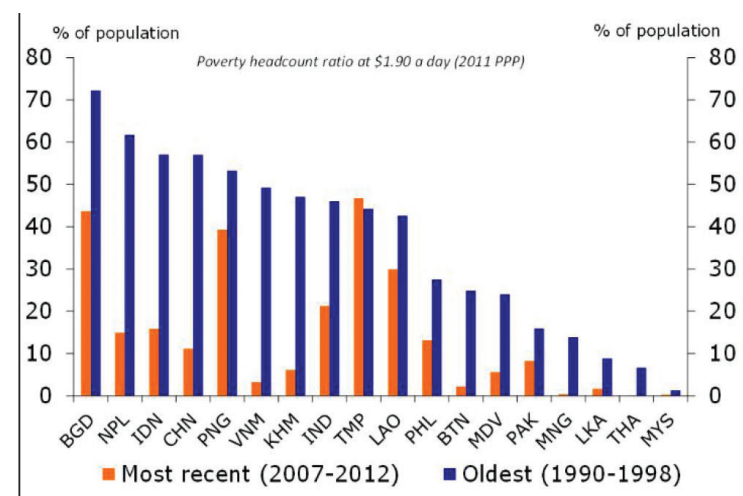

b. Ratio of Poor Population

Figure 2: Income Inequality and Poverty of Several Asian Countries Source: World Bank, 2016 
This phenomenon shows that there is a gap between the theoretical purposes of financial inclusion with the real circumstances in Asia. Several studies have proven strong positive relationship between financial inclusion and economic growth (Kendall et al., 2010; Ghosh, 2011; Sarma \& Pais, 2011; Mihasonirina \& Kangni, 2011; Masoud \& Hardaker, 2012; Demirguc-Kunt \& Klapper, 2012; Sharma, 2016; Pradhan et al., 2016; Kim, Yu, \& Hassan, 2018; Gul et al., (2018); Raza et al., 2019), while Naceur and Ghazouani (2007) and Khan (2011) shows that financial inclusion has a negative influence on economic growth.

Other studies also examine the relationship between financial inclusion, poverty, and income inequality in various countries with diverse methods and findings. Beck et al. (2007), Brune et al. (2011), Dixit and Ghosh (2013), Le and Nguyen (2020), and Sanjaya (2014) stated that financial inclusion can reduce poverty and income inequality. Park and Mercado (2015), Schmied and Marr (2016), and Boukhatem (2016) also found empirical evidence of a negative relationship between financial inclusion, poverty, and income inequality. On the contrary, Dhrifi (2013), Seven and Coskun (2016), and Neaime and Gaysse (2018) found that financial inclusion does not have a significant influence on poverty and income inequality.

Likewise, there are different findings on the relationship between financial inclusion and financial stability. Hanning and Jansen (2010), Prasad (2010), Morgan and Pontines (2014), Dienillah and Anggraeni (2016), Ozili (2018), Neaime and Gaysse (2018), and Ahamed and Mallick (2019) found that financial inclusion positively influences financial stability. Sanusi (2011) argues that there is no economy that can achieve financial stability, economic sustainability, and inclusive growth without achieving a high level of financial inclusion. Different results on the impact of financial inclusion and financial system stability were obtained by Khan (2011) and Mehrotra and Yetman (2015) who stated that financial inclusion negatively influenced financial stability. In addition, Dupas et al. (2012) added that the increase in banking services did not cause an increase in financial stability because it was not followed by a decrease in borrowing costs for the lower middle class as well as an increase in service quality, and lack of trust.

The phenomenon of the increase of a quite rapid financial inclusion in Asia that is not accompanied by increased economic growth and reduction of income inequality, as well as inconsistent research findings and the lack of comprehensive research that examines the impact of financial inclusion on economic growth, poverty, income inequality, and financial stability becomes the main basis for the author to examine the influence of financial inclusion toward economic growth, poverty, income inequality, and financial stability in Asia. The results of this study will help policy makers to design and implement programs that will expand access to financial services, which lead to increased economic growth, poverty reduction, income distribution, and financial stability, which in turn will be able to help achieve sustainable development.

\section{Literature Review}

\subsection{Financial Inclusion and Economic Growth}

Economic growth is an achievement through a process supported by various sectors in the economy, one of which is the financial sector. There are four roles of the financial sector that are beneficial for the economy, namely: (1) being able to reduce risk; (2) mobilize savings; (3) reduce transaction and information costs; and (4) encourage specialization (Levine, 2005). Furthermore, Fabya (2011) added that the financial sector is able to provide borrowers various financial instruments with high quality and low risk, which ultimately will accelerate economic growth.

Several studies have examined the relationship between financial inclusion and economic growth. Kendall et al. (2010) and Ghosh (2011) evaluate the role of financial access in economic growth with the data from Indian subnational level which proves the positive impact of access to financial services and use of financial services on economic growth in India. Mihasonirina and Kangni (2011) also found the significance of financial inclusion and communication technology toward economic growth. Martinez et al. (2011) argued that access to finance is an important policy tool used by governments and policy makers to stimulate economic growth. By making finance available and affordable for all economic agents, it will affect the growth of economic activities that will increase the output. Sarma and Pais (2011) found empirical evidence of a relationship between financial inclusion and economic growth using data from 49 countries. Falahaty and Hook (2013) showed that financial development is a significant determinant of economic growth. This finding shows that improving the function of the banking sector is very crucial to spur economic growth. Law, Azman-Saini, and Hui (2014) emphasized that a welldeveloped financial system is essential for economic growth. Furthermore, Sarma (2016) continued the study by analyzing the causality relationship between various dimensions of financial inclusion and economic growth, which proves that there is a two-way causality relationship between access to banking services and economic growth. Recently, Pradhan et al. (2016), Kim et al. (2018), and Raza et al. (2019) proved that there is a significant positive relationship between financial inclusion and economic growth.

On the contrary, Naceur and Ghazounai (2007) examined the relationship between financial development and economic growth for 11 countries in the Middle East and North Africa and found that bank development has a 
negative influence on economic growth. Khan (2011) also showed that financial inclusion has a negative influence on economic growth. Financial inclusion can lower loan standards because financial institutions are trying to reach the lower community by lowering loan terms, but it can also increase the risk of a bank's reputation, as several countries lower the standard of establishing financial institutions for rural areas.

\subsection{Financial Inclusion, Poverty, and Income Inequality}

Financial inclusion can lift the financial condition and standard of living of poor and reduce income inequality (Beck et al, 2007). According to Brune et al. (2011), saving allows families to increase their capacity to absorb financial shocks, smooth consumption, accumulate assets, and invest in health and education. Access to financial services has the potential to remove the poor from the cycle of poverty through a culture of saving and creating efficient and lowcost payment mechanisms (Dixit \& Ghosh, 2013). Sanjaya (2014) obtained results that financial inclusion through micro credit programs can improve social and economic status of the poor. Park and Mercado (2015) found empirical evidence of a negative relationship between financial inclusion, poverty, and income inequality. Boukhatem (2016) investigated the contribution of financial development level on poverty reduction in 67 low and middle income countries during 1988-2012 and found that the increase of financial development directly influences poverty reduction.

Dhrifi (2013) obtained different findings that financial development encourages economic growth and reduces poverty in middle and high income countries, while in lowincome countries, the financial system does not have positive influence on economic growth. On the other hand, Nguyen et al. (2020) conducted research in Vietnam and found that economic growth positively contributes to poverty reduction. Seven and Coskun (2016) stated that although financial development encourages economic growth, it does not necessarily benefit low-income people in developing countries, as they found that financial inclusion does not play an important role in poverty reduction. The latest research conducted by Neaime and Gaysse (2018) found that financial inclusion does not have significant influence toward poverty.

\subsection{Financial Inclusion and Financial Stability}

Financial inclusion can have both positive and negative influences on financial stability. The positive influence includes diversification of bank assets, increasing stability of deposit base, and increased monetary policy transmission, while the negative influence includes a decrease in loan standards, bank reputation risk, and inadequate regulations.

Hannig and Jansen (2010) argued that financial inclusion also has the potential to improve financial stability, because poor people's access to formal financial institutions' savings can increase household capacity to manage financial vulnerabilities caused by the adverse effects of the crisis, diversify the funding base from financial institution that can reduce shocks when global crisis occur, increases economic resilience by accelerating growth, facilitate diversification, and reduce poverty. Prasad (2010) added that at the state level, financial inclusion can increase efficiency in financial intermediation through domestic savings and increase in investment to encourage financial stability. Aduda and Kulanda (2012) examined financial inclusion and financial stability in Kenya, and found that financial inclusion is a perquisite for economic growth and development because various financial programs have an impact on Kenya's financial stability. Morgan and Pontines (2014) stated that an increase in availing by SMEs will increase financial stability. According to Dienillah and Anggraeni (2016), the increase of financial inclusion, banking assets, GDP per capita, and portfolio investment can be a good strategy to improve financial stability. Neaime and Gaysse (2018), Ahmed and Mallick (2019), and Pham and Doan (2020) stated that the increase of financial inclusion positively contributes to financial stability.

Khan (2011) and Dupas et al. (2012) obtained different results regarding the relationship between financial inclusion and financial stability. Financial inclusion has a negative influence on financial stability, as it can reduce loan standards because financial institutions try to reach the lower-income groups by lowering loan terms (Khan, 2011). Dupas et al. (2012) found that an increase in banking services in Kenya does not lead to an increase in financial stability because it is not followed by a decrease in borrowing costs for the lower-middle-class, increase in service quality, and because there is a lack of trust. Financial inclusion achieved through rapid loan growth or fund intermediation that is not accompanied by proper regulation can negatively influence financial stability (Mehrotra \& Yetman, 2015). Based on the literature review, the hypothesis proposed in this study is:

H1. Financial Inclusion (banking penetration, access to banking services, and use of banking services) significantly influences Economic Growth in Asia.

H2. Financial Inclusion (banking penetration, access to banking services, and use of banking services) significantly influences Poverty in Asia.

H3. Financial Inclusion (banking penetration, access to banking services, and use of banking services) significantly influences Income Inequality in Asia. 
H4a. Financial Inclusion (banking penetration, access to banking services, and use of banking services) significantly influences Financial Stability (bank non-performing loans to total gross loans) in Asia.

H4b. Financial Inclusion (banking penetration, access to banking services, and use of banking services) significantly influences Financial Stability (Bank Z-Score) in Asia.

\section{Research Method}

The object of this study is 10 developing countries in Asia: Afghanistan, Bangladesh, Brunei Darussalam, India, Indonesia, Malaysia, Pakistan, Philippines, Singapore, and Thailand, which are selected on the basis of the Financial Inclusion Index published by the International Monetary Fund (IMF). The research period is based on the year after the crisis to the availability of the latest data, namely 2009-2018.

The independent variable of this study is Financial Inclusion $(\mathrm{X})$, which consists of banking penetration $\left(\mathrm{X}_{1}\right)$, indicated by population who has bank account; access to banking services $\left(\mathrm{X}_{2}\right)$, indicated by number of bank office and ATMs spread across an area; and use of banking services $\left(\mathrm{X}_{3}\right)$, indicated by amount of deposits and loans extended. The dependent variable used is economic growth $\left(\mathrm{Y}_{1}\right)$, indicated by GDP per capita growth; poverty $\left(\mathrm{Y}_{2}\right)$, indicated by the ratio of poverty numbers below the national poverty line (\% of total population); income inequality (Y3), indicated by Gini coefficient; and financial stability $(\mathrm{Z})$, indicated by bank Z-score and bank nonperforming loans to total gross loans. The data used in this study is annual secondary data collected from the World Bank, International Monetary Fund (IMF) database, and others.

Hypothesis testing is done using a dynamic data panel model of Generalized Method of Moments (GMM), following Rioja and Valev (2004), Beck et al. (2007a, b) and Neaime and Gaysse, (2018). To measure the strength of the relationship between financial inclusion and income inequality/poverty, researchers used the inflation rate control variable following Ravallion and Datt (1999), Easterly and Fischer (2001), Dollar and Kray (2002), and Neaime and Gaysse (2018). The equation for the dynamic panel data model to measure the influence of financial inclusion toward economic growth, poverty, and income inequality is as follows:

$$
Z_{i t}=\alpha_{i}+\sum_{j=1}^{P} \varphi_{j} Z_{i t-1}+\sum_{j=1}^{N} \gamma_{j} X_{j i t}+\sum_{k=1}^{L} \beta_{k} Y_{k i t}+\varepsilon_{i t},
$$

Note:

$\mathrm{i}=$ Cross-country units (country)

$\mathrm{t}=$ Period of time $\mathrm{t}$ (years)

$\mathrm{X}=$ Proxy for financial inclusion variable
$\mathrm{Y}=$ Independent economic variable vector (inflation)

$\mathrm{Z}=$ Proxy for variable of economic growth, poverty, and income inequality

$\alpha \mathrm{i}=$ Unobserved fixed effect

$\varepsilon i t=$ The error rate that distributed independently

Furthermore, to see how banking penetration, access to banking services, and use of banking services can improve financial stability, this equation is proposed:

$$
\mathrm{STAB}_{i}=\alpha+\sum_{j=1}^{N} b_{i j} X_{i j}+\sum_{k=1}^{L} \mathrm{c}_{i k} M_{i k}+\varepsilon_{i}
$$

Note:

$\mathrm{i} \quad=$ Cross-country units (country)

STAB $=$ Proxy for financial stability

$\mathrm{X}=$ Proxy for financial inclusion variable

$\mathrm{M} \quad=$ Vector of the factors related to country $\mathrm{i}$

$\mathrm{a}, \mathrm{bj}$, and ck $=$ Parameter

ci $\quad=$ Error rate

The vector of $\mathrm{M}$ variable includes: (1) Log population size; (2) GDP per capita growth; (3) Gini Coefficient for income inequality; and (4) The average inflation during the observation period. To avoid multicollinearity problems, the model is estimated using GMM estimation procedure for linear model in panel data context. Model estimation method enables AR (1) autocorrelation type in the panel and crosssectional and heteroscedasticity correlation across panels.

\section{Results and Discussion}

\subsection{Descriptive Statistic Analysis}

The descriptive statistic of research variables is presented in Table 1. This shows that there is a large financial inclusion gap between 10 developing countries in Asia as shown by the significant difference between minimum and maximum value of the indicators. The data variation for the "number of commercial bank branch offices' is low, as indicated by the standard deviation value of 4.979. Likewise, data variations for the number of ATMs, Outstanding Deposits with Commercial Banks, and Outstanding Loans from Commercial Banks are not too high. Thus, the dimension of access to and use of banking services in Asian countries are not much different.

The dependent variable of economic growth indicated by GDP per capita growth shows quite high data variation. There is a fairly high difference in poverty in 10 Asian countries, while the variation level of income inequality and financial stability in these countries is still low. This indicates that the income inequality and financial stability between these countries are not much different (see Table 1). 
Table 1: Descriptive Statistics of Financial Inclusion and Economic Growth Indicator of 10 Asian Countries during 2009-2018

\begin{tabular}{|l|c|c|c|c|c|c|}
\hline & Min. & Max. & Average & Std. Dev & Skewness & Kurtosis \\
\hline Number of Account at Commercial Bank & 88.126 & 2486.377 & 1187.037 & 781.404 & 0.180 & -1.513 \\
\hline Number of Commercial Bank Branch Office & 2.019 & 23.682 & 10.847 & 4.979 & 0.634 & 0.652 \\
\hline Number of Commercial Bank ATMs & 0.452 & 117.279 & 38.099 & 33.663 & 0.646 & -0.661 \\
\hline Outstanding Deposits with Commercial Banks & 18.249 & 140.695 & 61.829 & 33.991 & 0.955 & 0.007 \\
\hline Outstanding Loans from Commercial Banks & 2.958 & 152.200 & 50.466 & 39.507 & 1.068 & 0.098 \\
\hline Economic Growth & -3.624 & 18.515 & 3.252 & 3.421 & 0.708 & 3.548 \\
\hline Poverty & 0.400 & 54.500 & 21.737 & 12.370 & 0.354 & 0.460 \\
\hline Income Inequality & 29.000 & 47.800 & 37.571 & 5.129 & 0.343 & -0.870 \\
\hline Bank Z-Score & 10.290 & 26.284 & 12.587 & 5.768 & 0.420 & -0.941 \\
\hline Bank nonperforming loans to total gross loans & 0.400 & 16.207 & 4.932 & 3.808 & 1.090 & 0.196 \\
\hline
\end{tabular}

Table 2: Results of the Influence of Financial Inclusion on Economic Growth in Asia

\begin{tabular}{|l|c|c|c|c|}
\hline Variable & Coefficient & Std. Error & t-Statistic & Prob. \\
\hline Economic_Growth(-1) & -0.176945 & 0.117217 & -1.509546 & 0.1355 \\
\hline Commercial_Bank_Branch & -0.003593 & 0.951857 & -0.003775 & 0.9970 \\
\hline Number_of_Account & -0.002741 & 0.003496 & -0.784256 & 0.4354 \\
\hline Number_of_ATM & 0.104014 & 0.072591 & 1.432877 & 0.1562 \\
\hline Outstanding_Deposit & -0.143703 & 0.228564 & -0.628722 & 0.5315 \\
\hline Outstanding_Loan & 0.408715 & 0.178321 & 2.292022 & $0.0248^{* *}$ \\
\hline Inflation & 0.128814 & 0.191530 & 0.672555 & 0.5034 \\
\hline F-statistic & 9.379025 & \multicolumn{2}{|c|}{ R-squared } & \multicolumn{2}{|c|}{0.376985} \\
\hline Prob(F-statistic) & $0.0000^{* * *}$ & Adjusted R-squared & \\
\hline
\end{tabular}

Note: ${ }^{* * *}$ Significant in $1 \%$ significance level

** Significant in $5 \%$ significance level

\subsection{Hypothesis Testing}

\subsubsection{The Influence of Financial Inclusion toward Economic Growth in Asia}

The hypothesis testing of the influence of financial inclusion toward economic growth in Asia is done using dynamic data panel model of Generalized Method of Moments (GMM) using EViews 7 application. The results are shown in Table 2:

Based on Table 2, it can be derived that simultaneously ( $\mathrm{F}$ test), financial inclusion significantly influences economic growth in Asia with 1\% significance level. However, the $\mathrm{R}^{2}$ of financial inclusion is very small, only $37.7 \%$. Thus, financial inclusion only explains the economic growth of $37.7 \%$, while $62.3 \%$ is explained by other variables.

It indicates that the increase of financial institutions in Asia can increase economic growth as shown in the graphic of economic growth development. The rapid increase in
3 dimensions of financial inclusions (banking penetration, access to banking services, and use of banking services) can increase economic growth in India, Bangladesh, Pakistan, Singapore, and Indonesia in 2013-2018. The increase of financial inclusion is aimed to create capital accumulation which in turn increases economic growth.

The financial inclusion through credit amount can increase investment in activities with high added value, thereby increasing economic growth through the country's output (Febya, 2011). By making finance available and affordable to all economic agents, the growth of economic activity will increase a country's output. Law, Azman-Saini, and Tan (2014) emphasized that a well-developed financial sector is essential for economic growth.

This finding is in accordance with Martinez et al. (2011) who stated that access to finance is an important policy tool used by governments and policy makers to stimulate economic growth. Sarma and Pais (2011); Sarma (2016); Sanjaya (2016); Kim et al. (2018), and Raza et al. (2019) 
also proved that financial inclusion significantly influences economic growth.

Based on the GMM test results summarized in Table 2, there is only one financial inclusion indicator that shows significantly positive influence toward economic growth, namely loan amount with $5 \%$ significance level. This shows that the loans amount disbursed by banks can significantly increase economic growth.

It is consistent with the focus of the National Financial Inclusion Strategy of 10 Asian countries which has become an object of research. Most of them focus on increasing the loan amount, especially for productive economic sectors including rural sectors such as agriculture and MSMEs in countries like Afghanistan, and Indonesia. Government and central bank of Bangladesh have intensified efforts to increase financial inclusion with refinancing loans to farmers, micro and small enterprises, renewable energy, and waste treatment projects.

Bank loans have an important role in financing a country's economy. The availability of loans enables households companies to consume better and make investments that cannot be done with their own funds. Thus, an increase in loans extended by banks will increase productivity so that the level of economic growth can also be higher (Goldsmith, 1969; Beck et al. 2000; Christopouluos \& Tsionas, 2004). The increase of loan provision for productive sectors, especially agriculture and MSMEs, allows for significant increase in productivity thus economic growth can be achieved optimally.

Other indicators of financial inclusion dimensions, namely the number of accounts at commercial banks, the number of commercial bank branches, number of ATMs, and number of deposits have no significant effect on economic growth. This is possibly because these indicators do not directly influence economic growth.

\subsubsection{The Influence of Financial Inclusion toward Poverty in Asia}

The hypothesis test results of the influence of financial inclusion toward poverty in Asia are shown in Table 3. Simultaneously (F test), financial inclusion significantly influences poverty in Asia with 1\% significance level. The $\mathrm{R}^{2}$ of financial inclusion toward poverty is $69.5 \%$. Therefore, financial inclusion can explain poverty of $69.5 \%$, while $31.5 \%$ is explained by other variables.

These findings prove that the increase of financial inclusion in Asia can reduce poverty levels. This is consistent with the poverty rate development which shows a decline from 2013 to 2018 in Pakistan, Bangladesh, India, Indonesia, Malaysia, Philippines, and Thailand. Inclusive financial system plays an important role in poverty alleviation. People with access to financial services tend to be more productive by consuming and investing more to improve their standard of living (Ashraf et al., 2006). Financial inclusion will greatly help marginalized and low-income groups to increase their income, accumulate wealth, manage risks, and make efforts to get out of poverty.

One of the main objectives of the National Financial Inclusion Strategy is to increase community welfare and poverty alleviation through increasing access of the lower middle class to the formal financial system. Access for the poor to formal financial institutions can increase household capacity to manage financial vulnerabilities caused by the adverse effects of the crisis, diversify the funding base from financial institutions, increase economic resilience by accelerating growth, facilitate diversification, and reduce poverty (Hanning \& Jansen, 2010). Lack of access to finance can adversely affect economic growth and poverty alleviation, as the poor find it difficult to accumulate savings, build assets to protect themselves from risks, and invest in income-generating projects.

These results are consistent with Dixit and Ghosh (2013) who stated that access to financial services has the potential to reduce poverty rate. Financial inclusion through micro credit programs can increase social and economic status of the poor (Sanjaya, 2014). Beck, et al. (2007), Brune et al. (2011); Park and Mercado (2015); Boukhatem (2016) also found empirical evidence of significant negative influence between financial inclusion and economic growth. (See Table 3)

Based on GMM test results in Table 3, it can be deducted that there are two partial financial inclusion indicators that show significantly negative influence on economic growth and these two partial indicators are number of commercial bank branches and number of accounts in commercial banks with $1 \%$ significance level. These two indicators enable families to access formal financial services in an easy and affordable way. Wider access to financial services for every population, especially for the poor and marginalized group with limited access to financial services provides opportunity to improve their living conditions and to become more prosperous.

Other financial inclusion indicators such as number of ATMs, saving amount, and loan amount do not have significant influence toward poverty. It is because the banking structure in several Asian countries is not sufficiently developed in terms of access and utilization of financial services that can effectively affect poverty alleviation. Moreover, financial inclusion in terms of the increased amount of savings and loans do not seem to reach large segments of the population, especially the poor (Pierce, 2011). Financial inclusion cannot be seen narrowly only by expanding public access to the formal financial sector and increased public interest in having savings accounts at banks, but it must be encouraged more to provide loan facilities (micro) both to individuals and MSMEs, thereby poverty alleviation can be achieved optimally.

The efficiency of the banking sector must be increased, especially in the use of financial service by providing more support to MSMEs (Neaime \& Gaysse, 2018). Ineffectiveness 
of the financial sector causes low productivity due to fund allocation that is not optimal. Likewise, an underdeveloped financial system causes low levels of competition, which makes long-term interest rates become relatively low and does not provide incentives for savings, and bank loan margins become relatively high that low-income groups or MSMEs cannot afford it. Financial system development must be enhanced, especially in rural areas where banking institutions need to expand their branch networks and facilitate funds flow and exchange to increase investment opportunities and improve people's lives.

\subsubsection{The Influence of Financial Inclusion toward Income Inequality in Asia}

Based on GMM test results for the influence of financial inclusion toward income inequality in Asia in Table 4, it is known that three financial inclusion indicators show significant negative influence toward income inequality in Asia, namely number of commercial bank branches, number of accounts, and saving amount with $10 \%$ significance level. This shows that in 10 Asian countries, these three indicators can reduce income inequality. A higher number of commercial bank branches will facilitate access to financial services for the poor, and eventually reduce income inequality.

The inflation rate also has a negative and significant influence on income inequality in Asia with 5\% significance level. Meanwhile, two other financial inclusion indicators, namely the number of ATMs and loan amounts do not have significant influence on income inequality. This is because the use of ATM and loan facility is used for consumptive activities instead of investment or working capital, thus it does not affect the income inequality (see Table 4).

Table 3: Results of the Influence of Financial Inclusion on Poverty in Asia

\begin{tabular}{|c|c|c|c|c|}
\hline Variable & Coefficient & Std. Error & t-Statistic & Prob. \\
\hline Poverty(-1) & 40.70460 & 2.903517 & 14.01907 & $0.0000^{* * *}$ \\
\hline Commercial_Bank_Branch & -1.020279 & 0.284871 & -3.581548 & $0.0005^{* * *}$ \\
\hline Number_of_Account & -0.011459 & 0.003166 & -3.619602 & $0.0005^{* * *}$ \\
\hline Number_of_ATM & -0.022918 & 0.037135 & -0.617148 & 0.5386 \\
\hline Outstanding_Deposit & 0.070364 & 0.087979 & 0.799784 & 0.4259 \\
\hline Outstanding_Loan & 0.013415 & 0.071527 & 0.187553 & 0.8516 \\
\hline Inflation & -0.157807 & 0.174865 & -0.902447 & 0.3692 \\
\hline F-statistic & 35.34424 & \multicolumn{2}{|c|}{ R-squared } & 0.695147 \\
\hline Prob(F-statistic) & $0.0000^{* * *}$ & \multicolumn{2}{|c|}{ Adjusted R-squared } & 75479 \\
\hline
\end{tabular}

Note : *** Significant in $1 \%$ significance level

Table 4: Results of the Influence of Financial Inclusion on Income Inequality in Asia

\begin{tabular}{|c|c|c|c|c|}
\hline Variable & Coefficient & Std. Error & t-Statistic & Prob. \\
\hline Gini_Index(-1) & 29.67063 & 1.231625 & 24.09064 & $0.0000^{* * *}$ \\
\hline Commercial_Bank_Branch & -0.225498 & 0.120838 & -1.866123 & $0.0652^{*}$ \\
\hline Number_of_Account & -0.002598 & 0.001343 & -1.934677 & $0.0561^{*}$ \\
\hline Number_of_ATM & 0.005207 & 0.015752 & 0.330574 & 0.7417 \\
\hline Outstanding_Deposit & -0.136747 & 0.037319 & -3.664257 & $0.0004^{*}$ \\
\hline Outstanding_Loan & 0.012493 & 0.030341 & 0.411764 & 0.6815 \\
\hline Inflation & -0.187852 & 0.074175 & -2.532546 & $0.0130^{* *}$ \\
\hline F-statistic & 25.68037 & \multicolumn{2}{|c|}{ R-squared } & 0.623607 \\
\hline Prob(F-statistic) & $0.0000^{* * *}$ & \multicolumn{2}{|c|}{ Adjusted R-squared } & 0.599324 \\
\hline
\end{tabular}

Note : *** Significant in $1 \%$ significance level

** Significant in $5 \%$ significance level

* Significant in $10 \%$ significance level 
Based on the $\mathrm{F}$ test, it is known that financial inclusion significantly influences income inequality in Asia with $1 \%$ significance level. This indicates that the increase of financial inclusion will reduce income inequality. $\mathrm{R}^{2}$ value of financial inclusion toward income inequality is $62.36 \%$. Thus, financial inclusion can explain income inequality for $62.36 \%$, while the $38.64 \%$ is explained by other variables.

This finding proves that the increase of financial inclusion in Asia can reduce income inequality, a negative trend (decline) for Gini index development, especially in Singapore, Thailand, Afghanistan, and Indonesia. Financial inclusion is an important element that creates inclusive growth because economic agents can make long-term consumption and investment decisions, participating in productive activities, and coping with unexpected short-term shocks with access to finance. Inclusive finance can increasingly provide wider access to financial services for the community, especially the poor and marginalized groups with limited access to financial services. Access to safe, easy, and well-functioning financial systems to the poor, disadvantaged areas, and disadvantaged sectors is a prerequisite for accelerating growth and reducing income inequality and poverty. It enables every part of the community to better integrate into the economy and actively contribute to development and protect themselves against economic shocks. Therefore, financial inclusion can encourage the income of the poor to increase, thus income inequality can be reduced.

This finding is consistent with the study conducted by Hannig and Jansen (2010), Beck, et al. (2007), and Park and Mercado (2015) who found a significant negative relationship between financial inclusion and income inequality.

\subsubsection{The Influence of Financial Inclusion toward Financial Stability in Asia}

Financial stability in this study is measured using bank non-performing loans to total gross loans, which reflects loan risks as a result of risk-taking behavior of each bank, and Bank Z-score, which measures the stability of the riskadjusted profitability achievement of the banking sector (Carretta et al., 2015). Bank Z-score is used as an indicator to measure financial stability that describes the probability of bank insolvency or bankruptcy; the higher the score, the better the financial stability is (Berger et al., 2009). Bank nonperforming loans to total gross loans reflect assets quality in loan portfolio and default risk of the banking sector. High bank non-performing loans to total gross loans indicate a large number of non-performing loans; as the bank has risks to experience failure and financial instability (Huang, 2005).

Table 5 shows that, simultaneously (F test), financial inclusion, economic growth, poverty, and income inequality significantly (sig. 1\%) influences financial stability in Asia represented by bank nonperforming loans to total gross loans indicator. This proves that financial inclusion along with economic growth, poverty, and income inequality has a significant impact on financial stability in Asia. $\mathrm{R}^{2}$ value of this model is $64.1 \%$, thus the independent variable in this model (financial inclusion, economic growth, poverty, income inequality) can explain financial stability variables (Bank nonperforming loans to total gross loans) of $64.1 \%$, while $35.9 \%$ is explained by other variables.

This finding proves that the increase of financial inclusion can increase financial stability. It is consistent, as it shows a negative trend of Bank nonperforming loans to total gross loans decline, especially in Philippines, Malaysia, Thailand, Indonesia, and Singapore. Financial inclusion can encourage financial stability by increasing the intermediating process between savings and investment. At macro level, financial inclusion attracts greater participation from various segments of the economy into the formal financial system. Financial inclusion brings individuals into the mainstream and makes monetary policy transmission more effective (see Table 5).

Based on Table 5, it is known that, partially, there is only one financial inclusion indicator that shows significantly positive influence on financial stability in Asia, namely the number of accounts in commercial banks. Therefore, when the number of accounts increases, financial stability will also increase. Economic growth, poverty, and income inequality also significantly influences financial stability in Asia. Other financial inclusion dimensions, namely access to banking services and use of banking services does not have significant influence on income inequality. This is because the large number of loans extended by banks actually increases the number of bad loans, thus bank nonperforming loans to total gross loans increases, although not significantly. Besides, from access to banking services dimension, financial inclusion can increase bank reputation risk because to improve financial service facilities, several countries lower the rules and required standards for financial institution establishment in rural areas. This may cause instability due to immature and insufficient regulations of microfinance institutions. Improved banking services does not increase financial stability because it is not followed by a reduction in borrowing costs for the lower middle class, an increase in service quality, and lack of trust (Dupas et al., 2012).

Table 6 summarizes the hypothesis test results of the influence of financial inclusion toward financial stability in Asia using Bank Z-score indicators. Four financial inclusion indicators significantly and positively influence financial stability in Asia, namely number of commercial banks, number of ATMs, savings amount, and total credit amount. Banking penetration dimension does not have any significant influence toward financial stability, because it does not directly influence financial stability indicated by Bank Z-score. 
Table 5: Results of the Influence of Financial Inclusion on Financial Stability in Asia (Bank Nonperforming Loans to Total Gross Loans)

\begin{tabular}{|c|c|c|c|c|}
\hline Variable & Coefficient & Std. Error & t-Statistic & Prob. \\
\hline Nonperforming_Loan(-1) & 24.51218 & 4.789399 & 5.118008 & $0.0000^{* * *}$ \\
\hline Commercial_Bank_Branch & 0.089041 & 0.102470 & 0.868944 & 0.3872 \\
\hline Number_of_Account & 0.004881 & 0.002255 & 2.164329 & $0.0339^{* *}$ \\
\hline Number_of_ATM & -0.017818 & 0.012370 & -1.440455 & 0.1532 \\
\hline Outstanding_Deposit & 0.033498 & 0.035341 & 0.947847 & 0.3458 \\
\hline Outstanding_Loan & -0.019080 & 0.031235 & -0.610849 & 0.5429 \\
\hline Economic_Growth & -0.159844 & 0.074041 & -2.158864 & $0.0336^{\star *}$ \\
\hline Poverty & 0.087227 & 0.033725 & 2.586412 & $0.0113^{* *}$ \\
\hline Gini_Index & -0.580877 & 0.078865 & -7.365486 & $0.0000^{* * *}$ \\
\hline Inflation & 0.058055 & 0.057133 & 1.016140 & 0.3123 \\
\hline Log_Population & -0.200955 & 0.439198 & -0.457550 & 0.6484 \\
\hline F-statistic & 15.88360 & \multicolumn{2}{|c|}{ R-squared } & 0.640892 \\
\hline Prob(F-statistic) & $0.0000^{* * *}$ & \multicolumn{2}{|c|}{ Adjusted R-squared } & 0.600542 \\
\hline
\end{tabular}

Note : ${ }^{* *}$ Significant in $1 \%$ significance level

** Significant in 5\% significance level

Table 6: Results of the Influence of Financial Inclusion on Financial Stability in Asia (Bank Z-Score)

\begin{tabular}{|c|c|c|c|c|}
\hline Variable & Coefficient & Std. Error & t-Statistic & Prob. \\
\hline Bank_Z_Score(-1) & -4.706432 & 6.593959 & -0.713749 & 0.4772 \\
\hline Commercial_Bank_Branch & 0.561800 & 0.141079 & 3.982159 & $0.0001^{* * *}$ \\
\hline Number_of_Account & 0.003165 & 0.001678 & 1.886367 & 0.0625 \\
\hline Number_of_ATM & 0.075482 & 0.017030 & 4.432218 & $0.0000^{* * *}$ \\
\hline Outstanding_Deposit & 0.224646 & 0.048657 & 4.616927 & $0.0000^{* * *}$ \\
\hline Outstanding_Loan & 0.163974 & 0.043004 & 3.813012 & $0.0003^{* * *}$ \\
\hline Economic_Growth & 0.137920 & 0.101938 & 1.352972 & 0.1795 \\
\hline Poverty & -0.003449 & 0.046432 & -0.074291 & 0.9409 \\
\hline Gini_Index & -0.404206 & 0.108580 & -3.722673 & $0.0003^{* * *}$ \\
\hline Inflation & -0.107584 & 0.078660 & -1.367714 & 0.1748 \\
\hline Log_Population & 0.226917 & 0.604679 & 0.375268 & 0.7084 \\
\hline F-statistic & 21.09667 & \multicolumn{2}{|c|}{ R-squared } & 0.703300 \\
\hline Prob(F-statistic) & $0.0000^{* * *}$ & \multicolumn{2}{|c|}{ Adjusted R-squared } & 9963 \\
\hline
\end{tabular}

Note: ${ }^{* * *}$ Significant in $1 \%$ significance level

For banks, financial stability helps provide a more stable base for deposits. Stable sources of retail funding (as opposed to reliance on borrowed funds) can increase bank resilience. Low-income savers and borrowers tend to maintain stable financial behavior in terms of saving and borrowing (loans). During the systemic crisis period, deposits from low-income customers acted as a sustainable source of funds although other credit sources dried up. Small customers provide great opportunities to accumulate stable deposits. Without such deposits, banks may find it difficult to continue lending. This credit line has the potential to deteriorate the crisis impact on the local economy more than it should have been (see Table 6). 
Table 6 shows that simultaneously ( $\mathrm{F}$ test), financial inclusion, economic growth, poverty, and income inequality significantly (sig. 1\%) influence financial stability in Asia represented by Bank Z-score indicators with control variables of inflation and population. $\mathrm{R}^{2}$ of this model is $70.3 \%$, thus the independent variable in this model can explain financial stability (Bank Z-score) of 70,3\%, while the $29.7 \%$ is explained by other variables.

This finding supports the study from Hannig and Jansen (2010); Prasad (2010); Aduda and Kulanda (2012); Morgan and Pontines (2014); Dienillah and Anggraeni (2016), and Neaime and Gaysse (2018) who stated that financial inclusion significantly influences financial stability.

Khan (2011) suggests three main ways of how financial inclusion can positively contribute to financial stability: (1) greater diversification of bank assets as a result of increased lending to small firms can reduce the risk of a bank's overall loan portfolio; (2) increasing the number of small savers will increase the size and stability of the deposit base and reduce bank reliance on 'non-core' financing, (3) contribute to better monetary policy transmission, which ultimately contributes positively to financial stability.

Hannig and Jansen (2010) argued that low income groups are relatively immune to economic cycles, so including them in the financial sector will tend to increase the stability of deposit and loan base. Khasnobis and Mavrotas (2008) stated that effective mobilization of domestic savings for private investment plays a key role in achieving economic growth and poverty reduction. Therefore, an efficient and inclusive financial system will empower individuals, facilitate goods and services exchange, integrate society with the economy, and provide protection against economic shocks. Prasad (2010) added that financial inclusion can increase efficiency in financial intermediation by increasing domestic savings and investment, thereby promoting financial stability. Increased loans by SMEs will increase financial stability and reduce the likelihood of failure of a financial institution (Morgan \& Pontines, 2014).

\section{Implication}

Theory implication provided in this study is financial inclusion can have positive impact on economic growth, poverty alleviation, income inequality reduction, and financial stability in Asia. However, not all dimensions of financial inclusion have significant impact. The government should give more attention to the implementation of steps to increase financial inclusion, thus the main objective of financial inclusion namely the increase of economic growth and financial stability and the reduction of poverty and income disparities can truly be achieved.

\section{References}

Aduda, J., \& Kalunda, E. (2012). Financial Inclusion and Financial Sector Stability with Reference to Kenya: A Review of Literature. Journal of Applied Finance and Banking, 2(6), $95-120$.

Ahamed, M. M., \& Mallick, S. K. (2019). Is financial inclusion good for bank stability? International evidence. Journal of Economic Behavior \& Organization, 157, 403-427

Amidžić, G., Massara, A., \& Mialou, A. (2014). Assessing Countries' Financial Inclusion Standing: A New Composite Index. IMF Working Paper Series No. WP/14/36. https://www. imf.org/external/pubs/ft/wp/2014/wp1436.pdf

Asian Development Bank. (2014). Financial Inclusion in Asia Country Surveys. Institute Working Paper. Asian Development Bank. https:/www.adb.org/sites/default/files/ publication/159308/adbi-financial-inclusion-asia.pdf

Bank Indonesia. (2013). National Strategy for Financial Inclusion. Jakarta, Indonesia: Central Bank of the Republic of Indonesia.

Bank Indonesia. (2014). Inclusive Finance Booklet. Jakarta, Indonesia: Bank Indonesia.

Beck, T., Demirguc-Kunt, A., \& Levine, R., (2007). Finance, Inequality, and the Poor. Journal of Economic Growth, 12(1), 27-49.

Beck, T., Demirguc-Kunt, A., \& Martinez, P. M., (2007). Reaching Out: Access to and Use of Banking Services Across Countries. Journal of Financial Economic, 85(1), 234-266.

Berger, A. N., Klapper, L. F., \& Turk-Ariss, R. (2009). Bank Competition and Financial Stability. Journal of Financial Services Research, 35(2), 99-118.

Bhanot, D., Bapat, V., \& Bera, S. (2012). Studying Financial Inclusion in North-East India. International Journal of Bank Marketing, 30(6), 465-484.

Bhaskar, P. (2013). Financial Inclusion in India. An Assessment. Speech at the MFIN and Access-Assist Summit, New Delhi, India.

Boukhatem, J. (2016). Assessing the Direct Effect of Financial Development on Poverty Reduction in a Panel of Low-And Middle-Income Countries. Research in International Business and Finance, 37, 214-230.

Brune, L., Giné, X., Goldberg, J., \& Yang, D. (2011). Commitments to Save: A Field Experiment in Rural Malawi. World Bank Policy Research Working Paper Series No. 5748. Washington, DC: World Bank. https://doi.org/10.1596/1813-9450-5748

Carretta, A., Farina, V., Fiordelisi, F., Schwizer, P., \& Lopes, F.S.S. (2015). Don't stand so close to me: The role of supervisory style in banking stability. Journal of Banking \& Finance, 52, $180-188$.

Chakravarty, S. R., \& Pal, R. (2013). Financial Inclusion in India: An Axiomatic Approach. Journal of Policy Modeling, 35(5), 813-837. 
Collard S. (2010.) Toward financial inclusion in the UK: Progress and challenges. Public Money \& Management, 27(1), 13-20.

Cumming, D., Johan, S., \& Zhang, M. (2014). The Economic Impact of Entrepreneurship: Comparing International Datasets. Corporate Governance: An International Review. 22(2), $162-178$

Demirguc-Kunt, A., \& Klapper, L. (2012). Measuring Financial Inclusion: The Global Findex Database. World Bank Policy Research Working Paper Series No. 6025. Washington, DC: World Bank. https://openknowledge.worldbank.org/ handle/10986/6042

Dhrifi, A. (2013). Financial development and the growth inequality poverty triangle. International Journal of Economics, Finance and Management, 2(7), 472-481.

Dienillah, A. A., \& Anggraeni, L. (2016). Impact of Financial Inclusion on Financial System Stability in Asia. Bulletin of Monetary Economics and Banking. [Indonesian]

Dixit, R., \& Ghosh, M. (2013). Financial Inclusion for Inclusive Growth of India: A Study of Indian States. International Journal of Business Management \& Research, 3(1), 147-156.

Dollar, D., \& Kray, A. (2002). Growth is Good for the Poor. Journal of Economic Growth, 7(3), 195-225

Dupas, P., Green, S., Keats, A., \& Robinson, J. (2012). Challenges in Banking the Rural Poor: Evidence from Kenya's Western Province. NBER Working Paper No. 17851. Cambridge, MA: National Bureau of Economic Research. https://www.nber.org/ papers/w17851

Easterly, W., \& Fischer, S. (2001). Inflation and the Poor. Journal of Money Credit Bank, 33(2), 160-178.

Fabya. (2011). Analysis of the influence of financial sector developments on economic growth in Indonesia. Scientific Journal of the Faculty of Economics and Management. Bogor Agricultural Institute, Indonesia.

Falahaty, M., \& Hook, L. S. (2013). The Effect of Financial Development on Economic Growth in the MENA Region. Journal of Economic Cooperation and Development, 34(3), 35-60.

Ghosh, S. (2011). Does financial outreach engender economic growth? Evidence from Indian states. Journal of Indian Business Research, 3(2), 74-99.

Gul, F., Usman, M., \& Majeed, M. T. (2018). Financial Inclusion and Economic Growth: A Global Perspective. Journal of Business \& Economics, 10(2), 133-152.

Hannig, A., \& Jansen, S. (2010). Financial Inclusion and Financial Stability: Current Policy Issues. Asian Development Bank Institute Working Paper No. 259. Asian Development Bank. https://www.adb.org/sites/default/files/publication/156114/ adbi-wp259.pdf

Hassan, M. K., Sanchez, B., \& Yu, J. S. (2011). Financial Development and Economic Growth: New Evidence from Panel Data. The Quarterly Review of Economics and Finance, 51(1), 88-104.
Huang, D. F. (2005). The Predictive Power of Capital Adequacy Ratios on Bank Risk. Journal of Contemporary Accounting, $6(1), 1-22$.

Kendall, J., Mylenko, N., \& Ponce, A. (2010). Measuring financial access around the world. World Bank Policy Research Working Paper Series No. 5253. Washington, DC: World Bank. https:// www.cgap.org/sites/default/files/CGAP-Measuring-FinancialAccess-around-the-World-Mar-2010.pdf

Khan, H. R. (2011). Financial Inclusion and Financial Stability: Are They Two Sides of the Same Coin. The Indian Bankers Association and Indian Overseas Bank, India.

Khasnobis, B. G., \& Mavrotas, G. (2008) Financial Development, Institutions, Growth and Poverty Reduction. London, UK: Palgrave Macmillan.

Kim, D.-W., Yu, J.-S., \& Hassan, M. K. (2018). Financial inclusion and economic growth in OIC countries. Research in International Business and Finance, 43, 1-14.

Kumar, N. (2013). Financial inclusion and its determinants: evidence from India. Journal of Financial Economic Policy, $5(1), 4-19$.

Law, S. H., Azman-Saini, W. N., \& Tan, H. B. (2014). Economic Globalization and Financial Development in East Asia: A Panel Cointegration and Causality Analysis. Emerging Markets Finance and Trade, 50(1), 210-225.

Le, Q. H., \& Nguyen, B. N. (2020). The Impact of Credit on Income Inequality in Vietnam. Journal of Asian Finance, Economics, and Business, 7(5), 111-118. https://doi.org/10.13106/ jafeb.2020.vol7.no5.111

Levine, R. (2004). Finance and Growth: Theory and Evidence. NBER Working Paper No. 10766. Cambridge, MA: National Bureau of Economic Research. https://www.nber.org/papers/ w10766

Masoud, N., \& Hardaker, G. (2012). The Impact of Financial Development on Economic Growth: Empirical Analysis of Emerging Market Countries. Studies in Economics and Finance, 29(3), 148-173.

Mehrotra, A., \& Yetman, J. (2015). Financial Inclusion: Issues for Central Banks. BIS Quarterly Review, 2015(March), 83-96. https://www.bis.org/publ/qtrpdf/r_qt1503h.pdf

Mihasonirina, A., \& Kangni, K. (2011). ICT, Financial Inclusion, and Growth: Evidence from African Countries. International Monetary Fund Working Paper No. WP/11/73. Washington, DC: International Monetary Fund. https://www.imf.org/ external/pubs/ft/wp/2011/wp1173.pdf

Martinez, M. V. (2011). The Political Economy of Increased Financial Access. Thesis, Georgetown University, Washington, DC.

Morgan, P., \& Pontines, V. (2014). Financial Stability and Financial Inclusion. Asian Development Bank Institute Working Paper No. 448. Asian Development Bank.

Naceur, S. B., \& Samir, G. (2007). Stock Markets, Banks, and Economic Growth: Empirical Evidence from the MENA 
Region. Research in International Business and Finance, 21(2), 297-315.

Neaime, S., \& Gaysse, I. (2018). Financial inclusion and stability in MENA: Evidence from poverty and inequality. Finance Research Letters, 24, 230-237.

Nguyen, H. T. T., Nguyen, C. V., \& Nguyen, C. V. (2020). The Effect of Economic Growth and Urbanization on Poverty Reduction in Vietnam. Journal of Asian Finance, Economics, and Business, 7(7), 229-239. https://doi.org/10.13106/ jafeb.2020.vol7.no7.229

Park, C.-Y., \& Mercado, R. (2015). Financial Inclusion, Poverty, and Income Inequality in Developing Asia. Asian Development Bank Economics Working Paper Series No. 426. Asian Development Bank. https://www.adb.org/sites/default/files/ publication/153143/ewp-426.pdf

Pham, M. H., \& Doan, T. P. L. (2020). The Impact of Financial Inclusion on Financial Stability in Asian Countries. Journal of Asian Finance, Economics, and Business, 7(6), 47-59. https:// doi.org/10.13106/jafeb.2020.vol7.no6.047

Pearce D., (2011). Financial Inclusion in the Middle East and North Africa. World Bank Policy Research Working Paper Series No. 5610. Washington, DC: World Bank. https://doi. org/10.1596/1813-9450-5610

Pradhan, R. P., Arvin, B. M., Norman, N. R., Nair, M., \& Hall, J. H. (2016). Insurance Penetration and Economic Growth Nexus: Cross-Country Evidence from ASEAN. Research in International Business and Finance, 36, 447-458

Prasad, E. (2010). Financial Sector Regulation and Reforms in Emerging Markets: An Overview. NBER Working Paper No. 16428. Cambridge, MA: National Bureau of Economic Research. https://www.nber.org/papers/w16428

Ozili, P. K. (2018). Impact of Digital Finance on Financial Inclusion and Stability. Borsa Istanbul Review, 18(4), 329-340.

Ravallion, M., \& Datt, G. (1999). When is Growth Pro-Poor? Evidence from the Diverse Experiences of India's States. World Bank Policy Research Working Paper No. 2263. Washington, DC: World Bank. https://doi.org/10.1596/1813-9450-2263

Raza, M. S., Tang, J., Rubab, S., \& Wen, X. (2019). Determining the nexus between financial inclusion and economic development in Pakistan. Journal of Money Laundering Control, 22(2), 195209. https://doi.org/10.1108/JMLC-12-2017-0068
Rioja, F., \& Valev, N. (2004). Does One Size Fit All? A Reexamination of the Finance and Growth Relationship. Journal of Development Economics, 74(2), 429-447.

Sanjaya, I. M. (2014). Financial Inclusion and Inclusive Growth as a Poverty Alleviation Strategy in Indonesia. Bogor, Indonesia: Bogor Agricultural University.

Sansui, L. (2011). Financial Inclusion for Accelerated Micro, Small and Medium Enterprises Development: The Nigerian Perspective. Paper presented at the 2011 Annual Microfinance and Entrepreneurship Awards.

Schmied, J., \& Marr, A. (2016). Financial Inclusion and Poverty: The Case of Peru. Regional and Sectoral Economic Studies, Euro-American Association of Economic Development, 16(2), 29-40.

Sethi, D., \& Sethy, S. K. (2018). Financial inclusion matters for economic growth in India. International Journal of Social Economics, 46(1), 132-151. https://doi.org/10.1108/IJSE-102017-0444

Sharma, D. (2016). Nexus between Financial Inclusion and Economic Growth. Journal of Financial Economic Policy, 8(1), 13-36.

Sarma, M. (2012). Index of Financial Inclusion - A Measure of Financial Sector Inclusiveness. Berlin Working Papers on Money, Finance, Trade and Development No. 07/2012. https:// finance-and-trade.htw-berlin.de/fileadmin/HTW/Forschung/ Money_Finance_Trade_Development/working_paper_series/ wp_07_2012_Sarma_Index-of-Financial-Inclusion.pdf

Sarma, M. (2016). Measuring Financial Inclusion for Asian Economies. In: S. Gopalan \& T. Kikuchi (Eds.), Financial Inclusion in Asia. Palgrave Studies in Impact Finance. Palgrave Macmillan, London. https://doi.org/10.1057/978-1-137-58337-6_1

Sarma, M., \& Pais, J. (2011). Financial Inclusion and Development. Journal of International Development, 23(5), 613-628.

Seven, U., \& Coskun, Y. (2016). Does financial development reduce income inequality and poverty? Evidence from emerging countries. Emerging Markets Review, 26, 34-63.

Swamy, V. (2014). Financial Inclusion, Gender Dimension, and Economic Impact on Poor Households. World Development, $56,1-15$.

Yu, J. S., Hassan, M. K., \& Sanchez, B. (2012). A re-examination of financial development, stock markets development and economic growth. Applied Economics, 44(27), 3479- 3489. 